\title{
Neoliberalism and Elite Democracy in Ecuador (1981-2007)
}

\author{
Ricardo Restrepo Echavarría ${ }^{1}$ \\ ${ }^{1}$ Universidad Nacional de Educación, Azogues, Ecuador \\ Correspondence: Ricardo Restrepo Echavarría, Universidad Nacional de Educación, Azogues, Ecuador. E-mail: \\ ricardo.restrepo28@yahoo.co.nz
}

Received: June 13, 2017

doi:10.5539/res.v9n3p126
Accepted: June 27, 2017

Online Published: August 2, 2017

URL: http://doi.org/10.5539/res.v9n3p126

\begin{abstract}
This paper synthesizes the political economy of neoliberal elite democracy as a general trend and marks out its concrete historical manifestation in one of its more committed followers, Ecuador, from 1981 to 2007. As the American continent turned toward democracy, it also turned to neoliberal reforms. The neoliberal reforms espoused were performed under the theory of the primacy of personal security and property rights, the securement of which would lead to economic growth, leading to the benefit of society as a whole. The actual policies implemented, however, violated the personal security and property rights of many, while increasing inequality and promoting slow growth. A democracy that rules by formal elections to accumulate capital in elites without regard to truth and justice is an elite democracy. Elite democracy was the chosen politics of neoliberalism and neoliberalism was the chosen economics of elite democracy. This paper provides a synthetic panoramic view of the history of the rise and life of neoliberalism and elite democracy in Ecuador, starting with the death of Ecuador's first president of its current democratic era, continuing with the measures that lead to the steep accumulation of public debt for the gain of a few in the 1980's, and the deregulation of the banking sector and transfer of its losses to the public in the 1990's and the beginning of the Century, while growth lagged but inequality and political instability accentuated.
\end{abstract}

Keywords: Ecuador, politics, economy, policy, neoliberalism

\section{Introduction}

Neoliberalism is widely held as the dominant global political economy of the last few decades. It is widely characterized as promoting a (private) market ideology through the advocacy of the primacy of private ownership and security rights, to which a small state corresponds, promising respect for the integrity and prosperity of the individual through the resulting economic growth. The rise of neoliberalism, after its first appearance in the Pinochet dictatorship (1973-1990), came accompanied by the Third Wave Democratization of the late Twentieth Century, as Huntington (1991) called it. The small state, however, was substituted by minority elite dominance, held by the two pillars of: property accumulation of elites by dispossession of the majority in the name of property rights and free markets; and militarization and violence in the name of security and consensus. National economic growth was replaced by economic growth of elites, verified by sluggish national growth coupled with increased inequality. Ecuador was no exception to this world trend. This paper takes some steps toward developing and supporting this conception of neoliberalism, and explores the specific ways in which Ecuador's neoliberal period from 1981 to 2007 exemplified this more abstract dynamic structure. The aim is to contribute understanding of the nature of this global regime and, at the time, one of its more committed followers.

\section{Neoliberalism and Elite Democracy}

Breaking with classical theory, minimalist democracy separates justice from the ends of democratic state-form. Democracy in this form is but a method of leadership choice, based on privileging elites at the expense of the majority, to ensure regime stability. Universal rights and development for all are but a convenient mirage used in the political communication and electoral game to compete for power, both to criticize and diminish opponents, on the one hand, as well as to enlarge the positive image of your candidate or interest, on the other. There is no non-self-serving obligation to speak truthfully about the faults of your opponents nor the virtues of your policies, and once in office there is no obligation to comply with campaign promises and fighting for the common good of all (Schumpeter, 1942; Huntington, 1991; Roemer, 1999; Przeworski, 1999; DiPalma, 1990). 
Neoliberalism's economic model finds a particularly good fit with this form of democracy. The political communication of neoliberal leadership focuses on guaranteeing property rights, rights of contract and personal security, in a framework of market liberalization. To this end, it advocates state minimization. These categorical rights in the minimal state are not just good in themselves, they also promise a greater good: economic growth, which "trickles down" and "lifts all the boats", ensuring greater liberty for all. Now, political communication does not have to be truthful; it is but a means to power, covered under the mantle of the right of freedom of expression. The first neoliberal experiment largely increased violations of property rights, rights of contract and personal security rights. It also did not promote economic growth, as was the regional and world-wide neoliberal trend (Weisbrot, 2015). This was the Chilean experiment promoted by the Pinochet dictatorship from 1973 to 1989. Backed by a large military state, this regime violated the property rights of the people over their copper wealth by the dictatorship obtaining violent possession over it (Wenar, 2008; Meller, 2000; Restrepo, Vazquez, \& Garzón, 2016). The rights of contract of millions were violated by being coerced to sustain and endure the military dictatorship regime at gunpoint. The right to personal security of millions was violated by threat of torture and murder, made credible by the torture and murder of thousands (Comisión Nacional de Verdad y Reconciliación Rettig, 1990). The state was big to benefit selected elites and not even the promise of economic growth was satisfied. It took neoliberalism fourteen years of military dictatorship to come back to Allende years GDP per capita levels (Chang, 2007). While the economy stagnated, the top decile did grow by taking from the rest, as inequality increased.

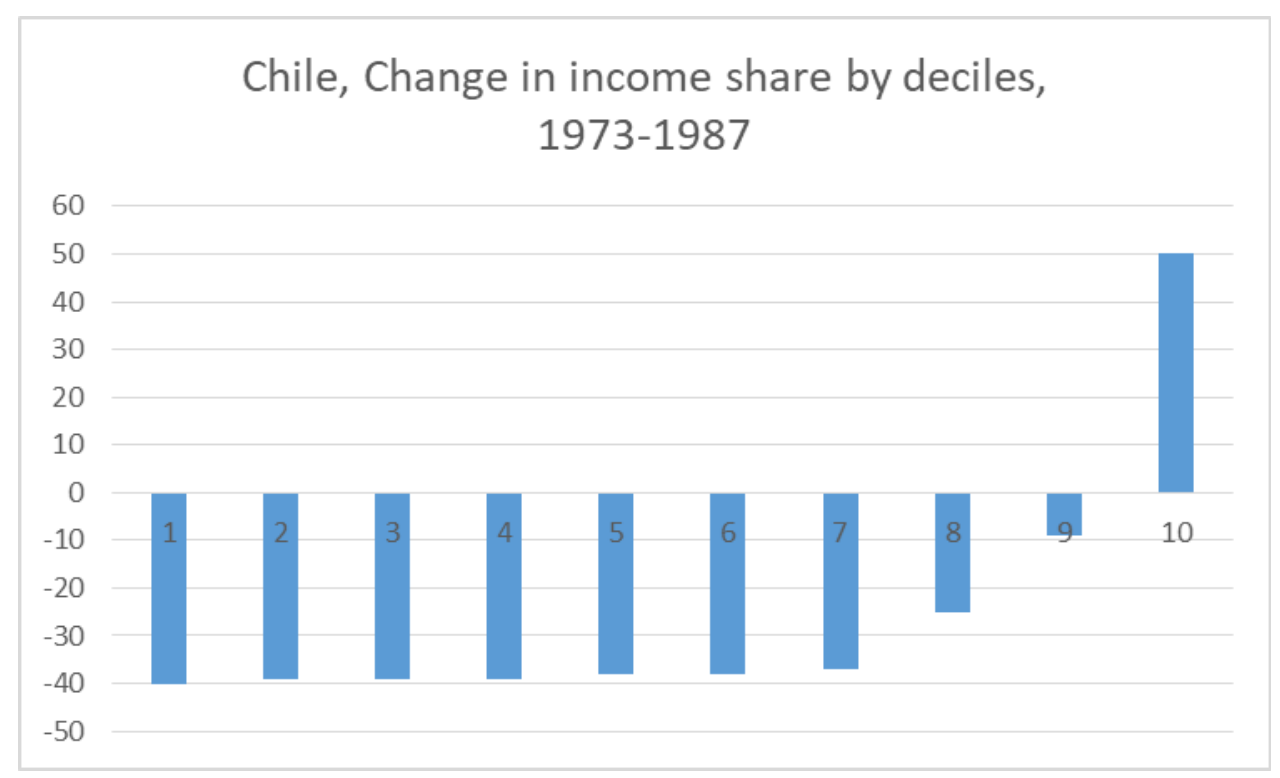

Figure 1. Percent change by decile. Calculated by Palma and Jervis, Palma (2014), with FACEA database (2012)

As if general freedom and economic success backed the neoliberal experiment in Chile, it was adopted region and world-wide, with similar results. Latin American GDP per capita growth performance in the central neoliberal years from 1981 to 2003, was dwarfed by the years before and after this period. 


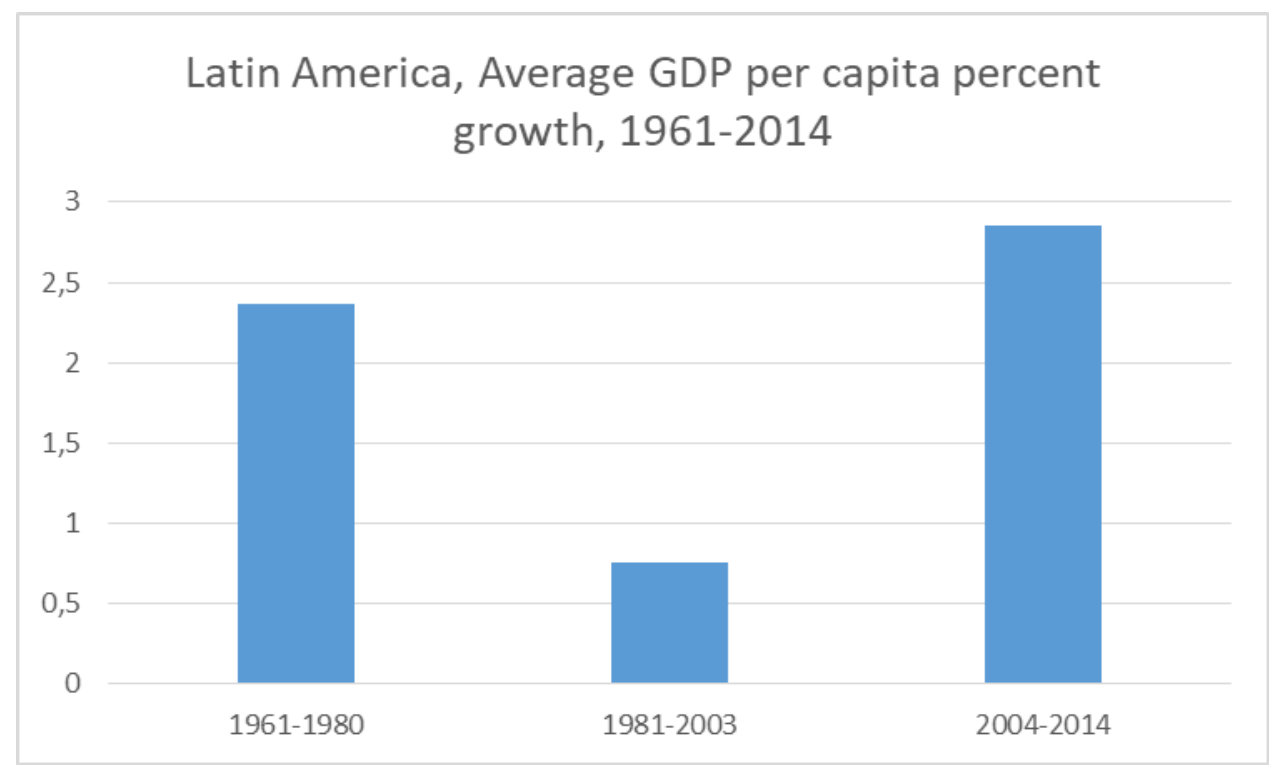

Figure 2. Author's calculations with World Bank data (2017)

While neoliberal policies were associated to less growth, they did serve to concentrate income. A dominant theme in the dynamic is reduction of state regulation of the financial sector, while financiers were kept immune from prosecution for fraud and other crimes, while keeping the profits of risky bets and transferred their losses to the public. We can see the inequality performance of the region in the neoliberal period with the Gini index.

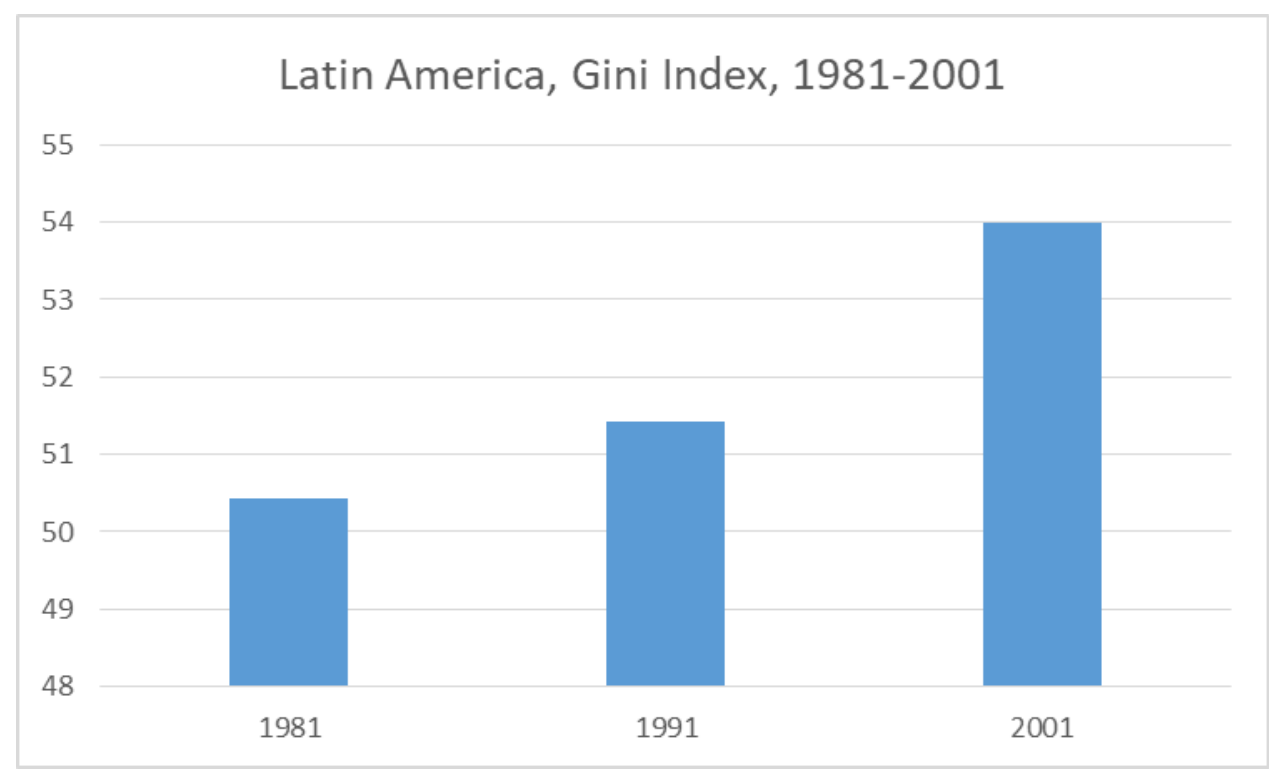

Figure 3. Author's calculations with World Bank data (2017)

In psychology, there is a turn to looking less at what people say and more at what people do. What people say counts, but we must understand how to interpret what is being said taking into account what people do. In economics, it is called "revealed preference". Likewise, we should not take what neoliberalism is at its word without looking at what it does. Neoliberalism in this sense turns out to be a strategy of selective state use of frequently financial, military and political elites to extract wealth from the rest and enrich themselves. The minimal state doctrine turns out to be minimalist democracy, at times tending to zero, as the state shrinks to not universalize rights (otherwise known as "austerity") and grows to ensure elite privilege. When minimal 
democracy tends to zero, especially when its promise of stability is undermined, it can be described as "false democracy".

The IMF Finance and Development journal in a recent article recognized the failed policies of financial capital liberalization and austerity for social rights as they tend toward crises (Ostry, Loungani, \& Furceri, 2016). It is democracy in appearance but its minimalist tendency has totally devoid it to the extent of being fake. Just as fake guns are mere apparent guns, false democracies are mere apparent democracies. Just as fake guns are fake because they cannot shoot bullets, fake democracies do not perform their minimal task of regime stability and leadership selection through institutionally established elections.

In the United States, a similar phenomenon of economic elite domination has occurred (Gilens \& Page, 2014), as institutions of the deregulated financial sector have become too big to fail and bankers too powerful to jail, driving economic crises and inequality (Barofsky, 2012; Greenwald, 2011). In the name of security and freedom, the military and prison industrial complexes top world incarceration, and arms production and public expenditure, driving widespread war and insecurity world-wide, as well as nationally, because of blowback and abusive policing and jailing (Fleurant, Perlo-Freeman, Wezeman, Wezeman, \& Kelly, 2016; Greenwald, 2011; Peláez, 2016). War criminals don't go to jail, while whistleblowers like Chelsea Manning do (Bugliosi, 2008).

Democracy is largely built on the assumption of government by the consent of the people. Of course, when you consent to a contract based on a lie, the contract is void. Minimalist democracy ignores this aspect of contractual rights and operationalizes consent as regime stability, evidenced by regular election cycles for leadership choice. While one may have neoliberal dictatorship as in the Chilean case, you may also have a neoliberal false democracy, when there are parties and elections with evident regime instability, as vast portions of the people actively reject the regime's leadership.

\section{From Neoliberal Minimalism to Neoliberal False Democracy in Ecuador}

The main hypothesis of this section is that approximately between 1981 and 1996, Ecuador deepened a neoliberal minimalist democracy model, which in turn became a neoliberal false democracy between 1997 and 2007. Democracy was reduced by specific forms of capital domination.

Jaime Roldós was ushered in as the first elected president of Ecuador since its return to democracy in 1979. Aiming to shed off the shadow of the preceding dictatorship and surrounded by repressive military rule in countries united under Plan Condor, Roldós made his central electoral agenda national and regional democratization, human rights and independent development, with popular national sovereignty over natural resources. Nationally, he formulated the nation's Development Plan (Paz y Miño, 2006), aimed to restructure the hydrocarbons sector, increased spending on education to highest in the region at 5.6\% of GDP (Aguirre, 2004), provided children in school with meals, reduced the workweek hours and doubled the minimum wage (Andes, 2016). Articulate denunciation of the human rights violations by the regional military dictatorships such as in Argentina, Chile, Bolivia and Brazil; helping and providing sanctuary to democratic forces abroad; promoting a "democratic block" centered around the Letter of Conduct signed by democratically elected governments, to counterweigh dictatorships; and support human rights and popular sovereignty over natural resources, were some of the concrete policies promoted by the Roldós administration. Soon after Ecuador, Panama and Perú refused to sign Plan Viola, promoted by the Argentine dictatorship, Roldós and his Defence Secretary Marco Subía, Panamanian president Omar Torrijos and the Peruvian Defence Minister César Hoyos died in plane crashes within weeks of each other. One of his most vocal critics and a key ally and friend of the Argentine dictatorship, with which he had recently met with, was the Commander of the Navy Raúl Sorroza, for whom Roldós had drafted a memo to separate from his post.

Roldós died in southern Ecuador just two years after Ecuador returned to democracy and the "legal" succession was handed down to vice president Osvaldo Hurtado, from the Popular/Christian Democracy Party, who instead of following up on Roldós' administrative action, promoted Roldós' enemy and prime murder suspect, Sorroza, to Defence Minister. Within eight days of the plane crash, the Armed Forces, designated to investigate themselves by its empowered principal suspect, dismissed the possibility of murder under the specious argument that it would have been "too risky" for the conspirators. According to the Armed Forces of Ecuador, who had enrolled Ecuador into Plan Condor in 1978 and who provided the basis for the dominant accident theory, conspiracies to assassinate are too risky to ever happen (Sarmiento \& Rivera, 2013) (Note 1).

While Roldós' agenda for a robust democracy was cut short, public debt rose substantively, for two mayor reasons. One, public debt obtained under military dictatorship at a $6 \%$ interest rate was not restructured using the res sic stantibus principle and "odious debt" doctrine. The res sic stantibus principle in international law applies when there is a "fundamental change" in the circumstances which "constituted an essential basis of the consent 
of the parties to be bound by the treaty", a condition clearly satisfied when it became a rate of $20.5 \%$, as the US Federal Reserve unilaterally lifted interest rates. The "odious debt" doctrine applies when signatories to national debt obligations clearly do not represent the interests of the nation, a condition satisfied by the fact it was a debt imposed by a military dictatorship and that less than $50 \%$ of the debt supposedly destined for national infrastructure could not be verified in the auditing process (Comisión para la Auditoría del Crédito Público, 2008, p. 51). Upholding these principles in the public interest would have legitimately unburdened the population. Instead the state followed the IMF and the Paris Club into a bubbling set of refinancing packages, called ERA83, ERA84 and MYRA. In the following projection we can see the radical transformation of the extent of debt obligations, where Ecuador would have paid this debt by 1993, but instead owed more than double the original by 2006 .

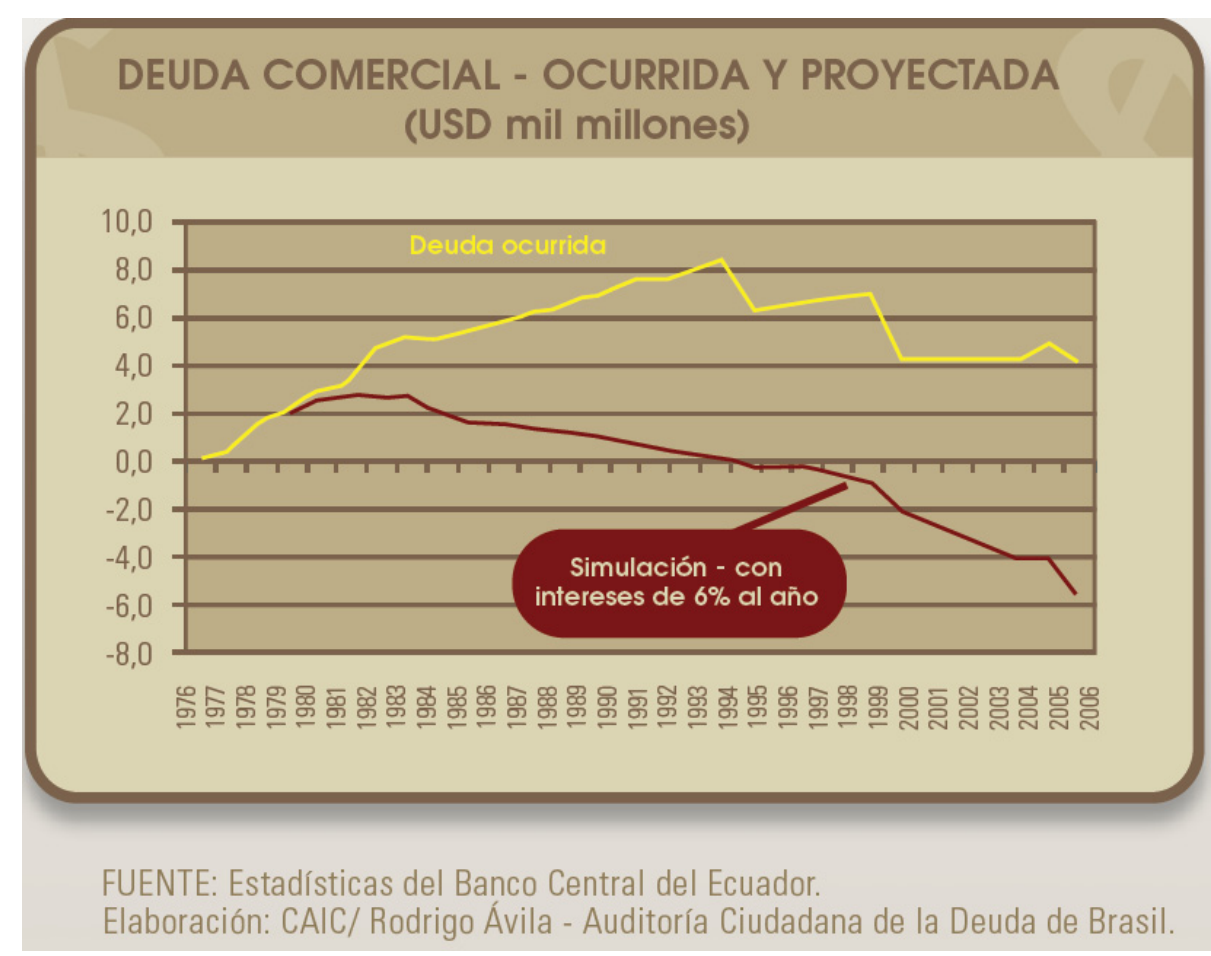

Figure 4. Comisión para la Auditoría Integral del Crédito Público (2008)

The second source of this robust reverse Robin Hood state intervention, was the so-called sucretización process, where well connected private agents transferred their international debts to Ecuador's Central Bank as the dollar rose in price. This process was formalized in 1983 under president Hurtado and deepened by president León Febres Cordero, of the Social Cristian Party, between 1984 and 1988. In the next graph we can see the growing result of the decisions made by those in state power to transfer private responsibilities to public debt, paid by all. 


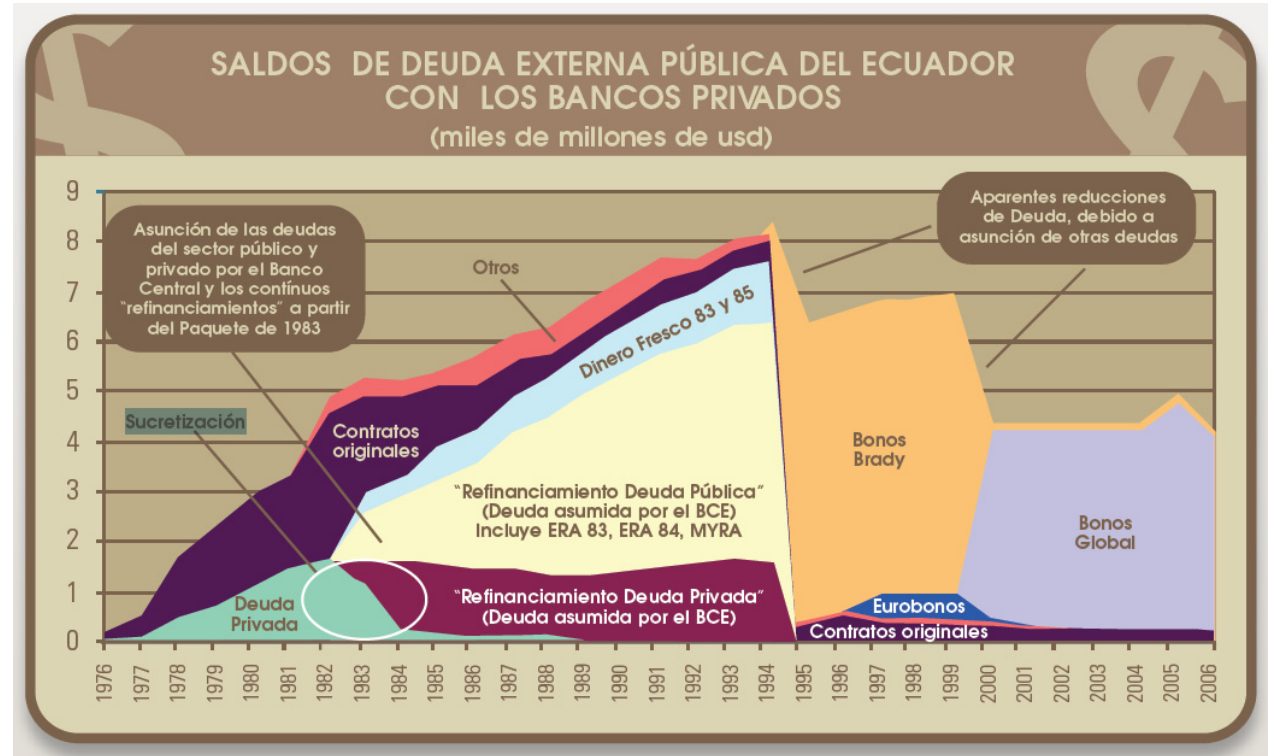

Figure 5. Comisión para la Auditoría Integral del Crédito Público (2008)

Without much visible benefit and public investment to represent the new obligations, Ecuador's proportional debt grew very significantly during this time. The best way to measure this is calculating the country's external debt as percentage of GDP per person, to thus find out how indebted the state has made each person on average, largely as a result of not rightfully defending the public interest against dictatorship and private sector liability burdens.

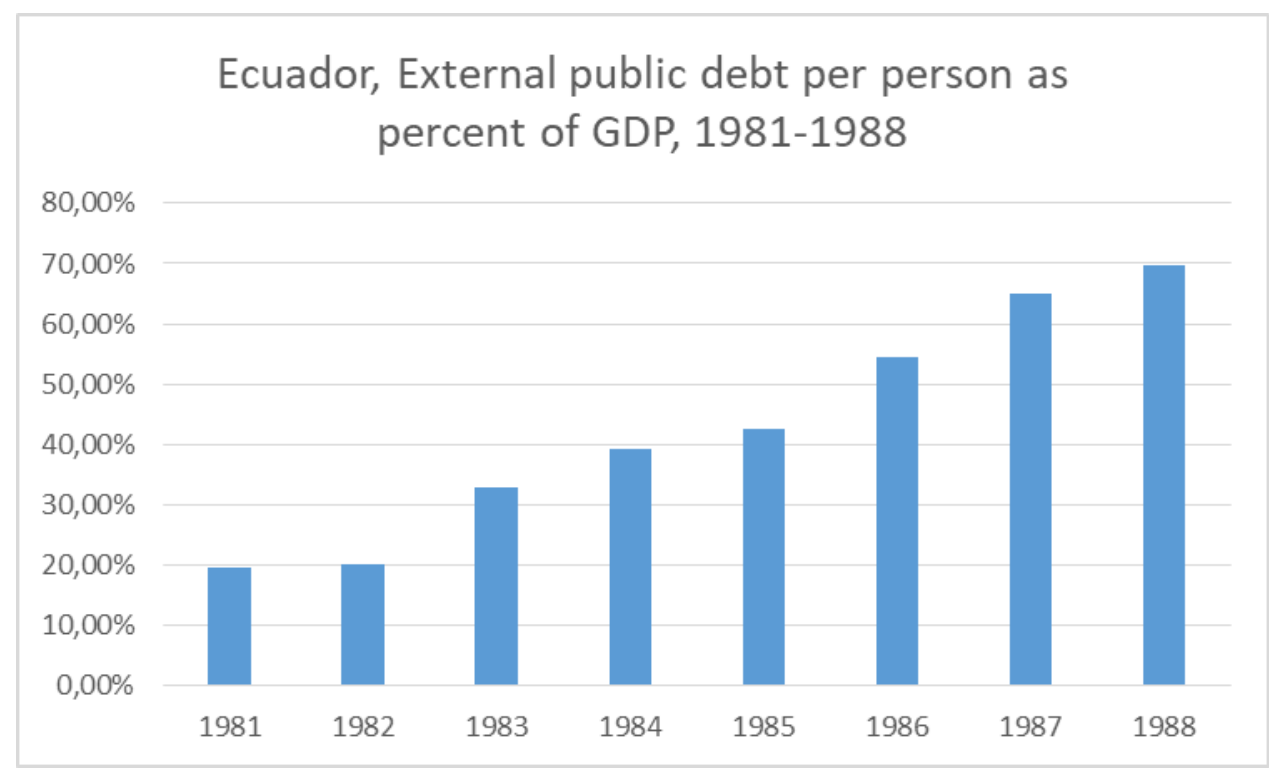

Figure 6. Author's calculations with World Bank data, 2016

The graph allows one to see a sevenfold multiplication of proportional public per person debt from 1976 to 1988 , and a $250 \%$ increase of proportional public per person debt from 1981 to 1988 . The leaders of the sucretization process, as it was called, justified this upward redistribution in violation of property rights by reference to saving the "national productive apparatus". What private luxury clubs, such as Quito Tennis and Golf Club, the Pacific Bank Club and the Horseshoe Riding Club, whose debts where transferred to the public, have to do with saving the national productive apparatus remains a mystery (Acosta, 2008). 
León Febres Cordero, a friend of Reagan's multiple military and economic wars in the Americas, disciplined the population by concentrating within his four years in office, $50 \%$ of total cases of state violations of human rights and $60 \%$ of the victims involving forced disappearance, torture and murder that happened between 1981 and 2008, as investigated by Ecuador's Truth Commission, together with the most salient crimes against humanity (Comisión de la Verdad, 2008, pp. 66-333). To provide political-judicial cover, he also imposed installing judges to Ecuador's Supreme Court by using tanks and tear gas.

From 1981 to 1996, the economy stagnated, spending 13 years below its 1981 level in real GDP per capita terms and averaging a $0 \%$ growth rate.

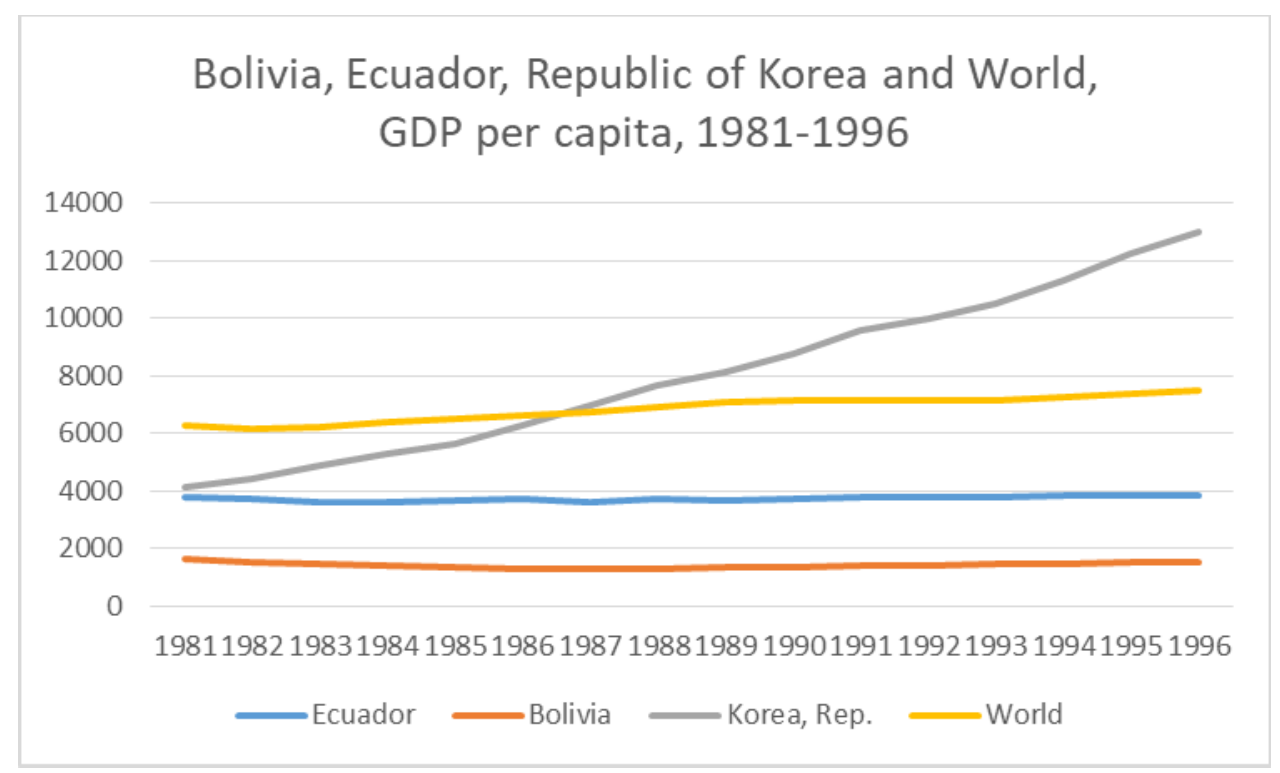

Figure 7. Author's calculations with World Bank data, GDP per capita (constant 2010 US\$)

While disciplining the population, the state could then benefit those who indebted the country, under the mantle of the flagship neoliberal discursive pillars of personal security, property and contract rights, and economic growth through state minimization. As murder rates almost doubled, Congress led by the Social Christian Party president Sixto Durán Ballén approved the economic, and particularly financial liberalization laws, to abolish public oversight and regulation over powerful corporate interests. The most important of these was the General Law of Institutions of the Financial System, which abolished key features of public oversight, regulation and control over banks and other financial institutions, increasing concentrated private profits while generalizing risk.

On top of escalating murder rates, the lack of consent of the population over the minimalist democratic neoliberal regime, was evidenced by the 1990 indigenous uprisings led by the indigenous movement Confederación de Nacionalidades Indígenas del Ecuador (CONAIE) and the ever-low trust and approval of the population over their political representatives (see below for opinion poll data).

Lastly, the Abdala Bucaram presidency marked the full emptying of the democratic content of the minimalist model and the beginning of a fully fake democracy, as not even the formal stability of leadership succession could be pointed at to mark its accordance with minimalist democratic theory. Not one elected president finished his or her constitutional period between 1996 and 2006. In this ten year period, Ecuador doubled it's already low historical average for political survival of heads of state. Heads of state would now last one year on average instead of two (its average since Independence in 1830). This included a brief military-civilian junta and the adoption of a new Constitution.

In this scenario, Bucaram was elected into the presidency in 1996 promising an anti-neoliberal turn to combat the oligarchical class and benefit the masses. "The crazy one who loves", as his slogan advertised, was pure demagoguery. Making the "responsible" move, however, by incorporating the argentine neoliberal reformer, Menem's former Economics Minister Domingo Cavallo, who once in power quickly adopted policies of austerity for the masses and largess for the well-off (Ruiz \& Cisneros, 2014), which caused the popular backlash 
which removed him from power as his political opponents in Congress activated the use of the Constitutional figure of being "mentally unable" in order to remove him. His vice president Rosalía Arteaga would last less than two days in the presidency and instead the head of Congress, Fabián Alarcón, was named president. To respond to the widespread popular dissatisfaction Fabián Alarcón organized a Referendum asking the population if there should be a new National Assembly to reform the Constitution and restructure the Supreme Court in order to guarantee its independence.

Members of the very unpopular political parties (14\% approval rating according to Latinobarómetro) formed the body of the National Assembly, especially the Social Christian Party and Popular/Christian Democracy Party, presided by former president Osvaldo Hurtado (Diario Hoy, 1997). In a military regiment in the outskirts of Quito, this body decided that they would not reform the 1978 Constitution as they were authorized to do; instead they would dispose of it altogether and impose another, thus usurping powers beyond their democratic mandate. The new 1998 Constitution, together with the creation of the publicly funded Agency to Insure Deposits, deepened the neoliberal vision of privatizing profit and socializing liabilities, already exemplified by the financial institutions law, by effectively providing for explicit free public insurance to banks, already operating in a risky deregulated environment. This Constitution, without the requisite consent to back its contractual democratic binding, formalized the death of minimalist democracy, the rise of false democracy, flourishing of neoliberalism and set the stage for a new upwards redistribution of the national wealth, as predictably, the banking system collapsed in 1999, under the presidency of Jamil Mahuad, from the Popular/Christian Democracy Party of Osvaldo Hurtado. This can be evidenced by increasing concentration of wealth measured by the Gini index in the available World Bank data years in the neoliberal period. The available data points show that the Gini inequality rose in the 90's with respect to the 80 's and rose up to 2007 with respect to the 90's.

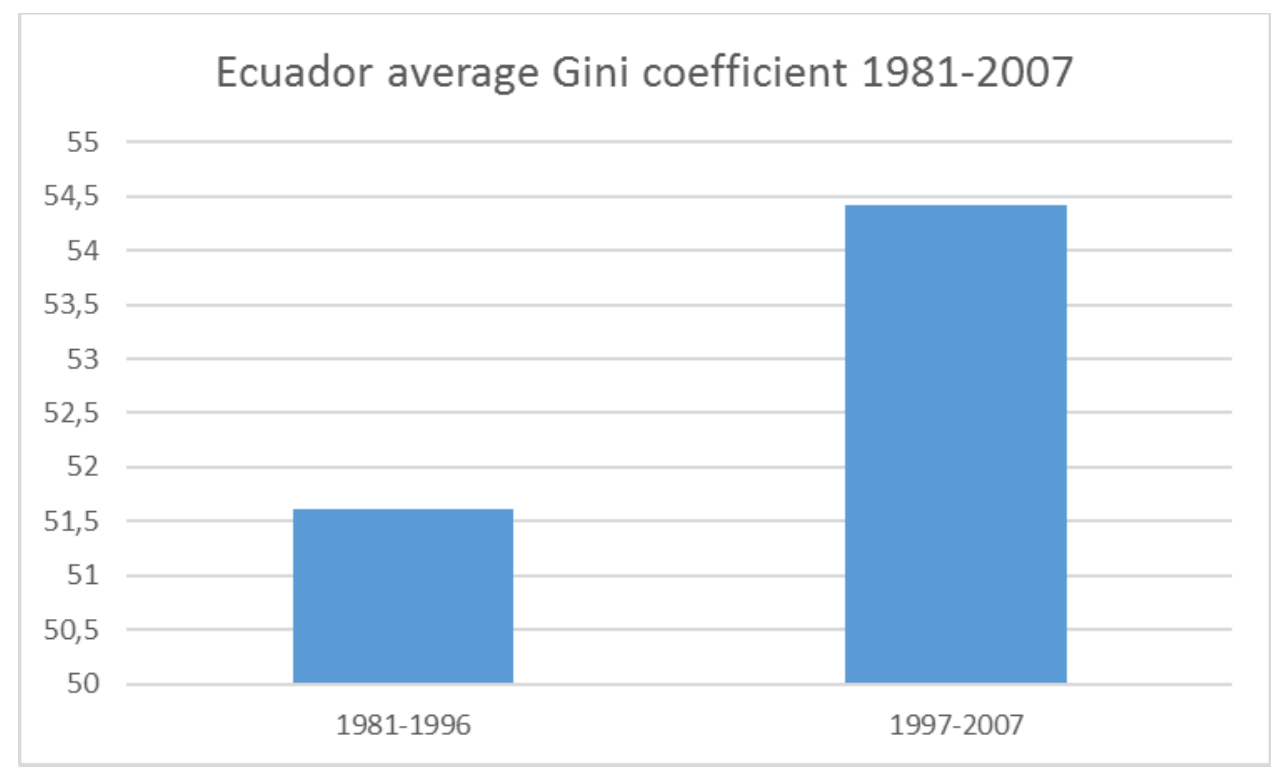

Figure 8. Calculations performed with the available World Bank data (2016)

The rising tide did not lift all the boats, as the tide did not in fact rise. Real GDP per person between 1997 and 2006 was but $1.3 \%$ on average per year and Ecuador did not have net growth at all between 1981 and 2006. 


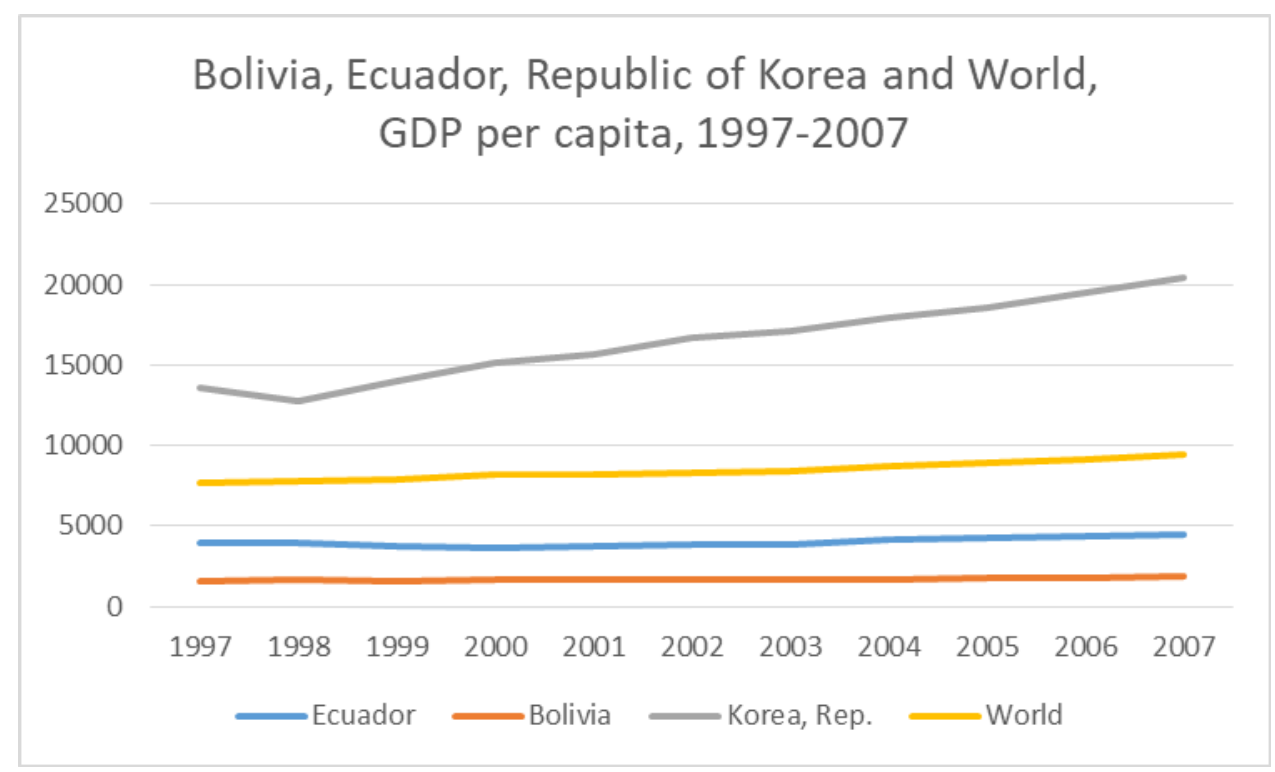

Figure 9. Author's calculations with World Bank data (2017)

Poverty and democracy stand in stark opposition. As Chomsky (1998) has noted, both Aristotle and Madison noticed this, though they opted for distinct responses. For if you have large segments of the population living under poverty, but with effective voting rights, they will vote to allocate resources in their favour, while the common good can be promoted as long as there is not large wealth inequality with large swaths of the population under poverty. So either you can reduce poverty or reduce democracy. Aristotle advocated for reducing poverty as way for democracy to serve the common good. As he put it, there would have to be "moderate and sufficient property" and "lasting prosperity" for everyone (Aristotle IV.11 1295b39-40). Madison, however, thought the purpose of government was "to protect the minority of the opulent against the majority" (Madison, 1787). Thus dividing up the population into factions that would check and balance one another so as to cancel each other out and the "people who own the country" could "govern it", as Jay put it (Jay, 1833, p. 70). Another way of reducing the tension between poverty and democracy is of course to expel that "tyrannical majority" from the country, thus reducing the possible poor voters. This is what happened in Ecuador with neoliberal policies, as approximately 1.5 million people, over $10 \%$ of the population, had to migrate mostly to the United States and Spain under the threat of deteriorating social conditions. As $50 \%$ of banks failed in the crisis of 1999 , poverty increased by $44 \%$ (CEPAL stats, 2016). Poverty hovered around $64 \%$ in the years just prior and after the turn of the Century. For the poor 6 of every 10 Ecuadorians the choice was: be poor or leave. The massiveness of the migration and the forces behind it can be inferred from that, in proportional and absolute terms, Ecuador's migration during the neoliberal period was twice that which happened during the Pinochet dictatorship in Chile. Their remittances constituted Ecuador's second major source of external income, after oil (Ramirez \& Ramirez, 2005; Jokisch, 2014; Doña \& Levinson, 2004).

In the restructuring of the Supreme Court, authorized to guarantee its independence, Febres Corderos's Social Christian Party was the "big winner" in getting their choices into the court, placing them in $50 \%$ of the seats and placing his "friend" Hugo Quintana Coello as the president of Ecuador's highest court (Diario Hoy, 2004; Conaghan, 2012; Restrepo, 2014). There would be no guaranteeing of the property rights of the people, as their assets were frozen for a year, and Mahuad decided to dollarize the economy, while decreasing the value of the Sucre by $60 \%$, effectively transferring the losses of failed economic policy and banking excesses to the general public. The Central Bank estimates the total cost of this bank failure at $\$ 6.170$ million, or just about a third of the year 2000's GDP (El Telégrafo, 2014; World Bank data, 2016). The economy sank $6.6 \%$ in negative growth (CEPAL stats, 2016). After losing the sovereign currency and consequently Ecuador's main instrument of economic policy, to instate the dollar as legal tender, before being ousted by a popular uprising protagonized by the indigenous movement, Mahuad did manage to further complicate future prospects of sovereign recovery. He did this by installing a US military base in the Manta port, without the congressional authorization demanded by the Constitution (1998, Articles 161, 162 and 276) imposed by the body presided by his party's own ex-president Osvaldo Hurtado. He also found the time to sign off on further assurance to the oil giant Chevron-Texaco, by 
releasing the company from liabilities to the government for dumping millions of barrels in the Amazon and its people (Zeitchik, 2014; Minister of Energy and Mines, Petroecuador and Texpet, 1998) (Note 2).

CONAIE head Antonio Vargas, jurist Carlos Solórzano and coronel Lucio Gutierrez assumed power briefly and called for new elections under Mahuad's vice-president Gustavo Noboa. Pachakutik, the political party of CONAIE, joined Gutierrez's Patriotic Society party, which brought him to power under a post neoliberal promise. As soon, however, as Gutierrez assumed office, he betrayed Pachakutik and his campaign promise, declaring himself the "best friend" of the United States to George W. Bush. Gutierrez enraged the population by once again stalking the Supreme Court, whose members largely from the Social Christian Party and Popular/Christian Democracy Party, immediately denounced the state in the Inter American Commission of Human Rights (Restrepo, 2014). Amidst loud calls for "all of them to go", in reference to the existing party system, agents and ruling class, Gutierrez fled the country and his vice president Alfredo Palacio finished out his term. This rejection can be seen in the following data. Between 1997 and 2007, Ecuador had eight heads of state and one civil-military junta, propelled by large protests and discontent among the population. Only $31 \%$ trusted the Supreme Court by 2005 (Seligson, Donoso, Moreno, \& Orcés y Schwarz-Blum, 2006, p. 82). Ecuador was second to last in the region in which its population believed itself to live in democracy; only $14 \%$ of the population were satisfied with democracy and in 2005 Ecuador had the highest percentage of the population in the region perceiving public servants to be corrupt (Latinobarómetro, 2005).

Ecuador, however, managed to pay the external debts of its ruling class.

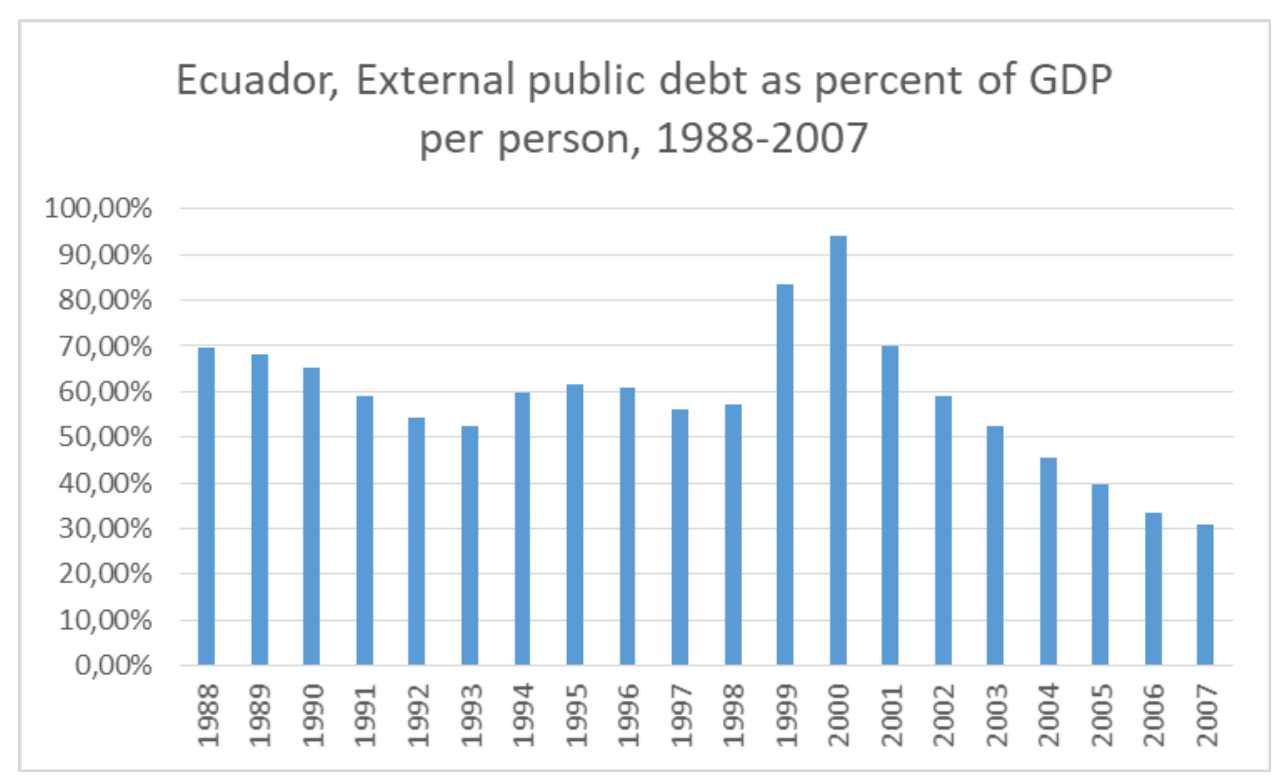

Figure 10. Author's calculations with World Bank data (2016)

During this tumultuous period of clear lack of consent for the existing regime, its principal agents, and their decisions to break contractual and property rights, the security of the right to life was also heavily undermined as murder rates almost tripled. 


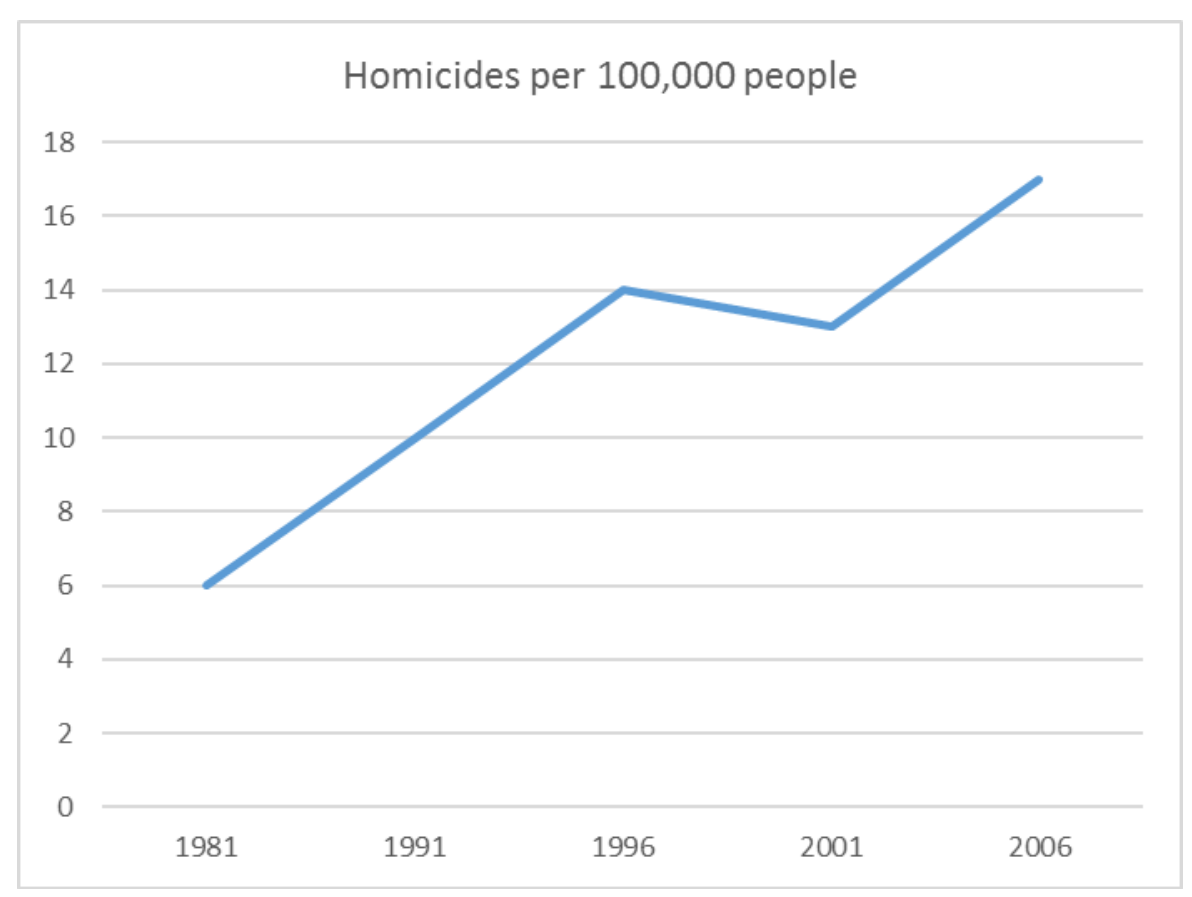

Figure 11. Author's calculations with data from Fundar (2005), World Health Organization (n/d), UNODC

(2013)

\section{Conclusion}

From universal property, contract and personal security rights, state minimization, and economic growth, to dispensing with neoliberalism and judicial independence through a referendum and "constitutional reform", broken promises characterized the neoliberal period, both in its minimalist as well as its false forms of democracy. In its minimalist form, Ecuadorian democracy between 1981 and 1996 concentrated wealth to privilege elites and recognized only this minority's rights. While, as its theorists think, it does not serve justice, it did secure a momentary stability for its institutional method of leadership choice. Between 1997 and 2007, formalized in a new imposed Constitution, this model completely broke down, as while all the minimalist pillars of justice-blindness, non-binding regime promises, exclusive elite privilege were maintained, with parties competing for power, the stability of the electoral method of leadership choice was severely undermined, thus minimizing to the point of faux democracy. Ecuador's unique experience was also an exemplification of the general trend of elite democracy and neoliberalism worldwide. This paper aims to show the main contours of that experience for further political thought and action, and serves to understand the groundwork that gave energy to the Citizens' Revolution headed by the then future president Rafael Correa, a topic for the subsequent analysis.

\section{References}

Acosta, A. (2008). Sucretización Un atraco al alimón? Quito: FLACSO.

Agee, P. (1975). Inside the company: A diary of the CIA. New York: Penguin Books.

Andes. (2016). Se recuerdan 35 años de la muerte del presidente Jaime Roldós Aguilera. Andes. Retrieved from

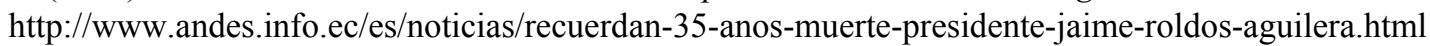

Aristotle. (2015). Politics. Adelaide: University of Adelaide.

Barofsky, N. (2012). Bailout: An inside account of how Washington abandoned Main Street while rescuing Wall Street. New York: Free Press.

Bugliosi, V. (2008). The prosecution of George W. Bush for murder. New York: Vanguard Press.

Chang, H. J. (2007). Bad samaritans: The myth of free trade and the secret history of capitalism. New York: Bloomsbury Press. 
Chomsky, N. (1998). That dangerous radical Aristotle. In The Common Good. Retrieved from https://chomsky.info/commongood02/

CIA. (1981). Roldós Struggling. In Latin American Review. Secret, Declassified, under FOIA.

Comisión de la Verdad. (2010). Sin verdad no hay justicia. In Informe final de la Comisión de la Verdad. Quito.

Comisión Nacional de Verdad y Reconciliación. (1990). Informe de la Comisión Nacional de Verdad y Reconciliación. Santiago: Gobierno de Chile.

Comisión para la Auditoría Integral del Crédito Público. (2008). Informe Final de la Auditoría Integral de la Deuda Ecuatoriana.

Conaghan, C. (2012). Prosecuting Presidents: The Politics within Ecuador's Corruption Cases. Journal of Latin American Studies, 44, 649-678.

Di Palma, G. (1990). To craft democracies: An essay on democratic transitions. Berkeley: University of California Press.

Diario, H. (1997). Las cifras oficiales de la Consulta Popular. Diario Hoy. Retrieved from http://www.explored.com.ec/noticias-ecuador/las-cifras-oficiales-de-la-consulta-popular-109591.html

Diario, H. (2004a). Hugo Quintana Preside la Corte Suprema. Diario Hoy. Retrieved from http://www.hoy.com.ec/noticias-ecuador/hugo-quintanapreside-la-corte-suprema-164942.html

Diario, H. (2004b). PSC retoma el control de la Corte Suprema. Diario Hoy. Retrieved from http://www.explored.com.ec/noticias-ecuador/psc-retomael-control-de-la-corte-suprema-164707.html

Diario, H. (2007). Corte Suprema de Justicia no da información sobre banqueros. Diario Hoy.

Doña, C., \& Levinson, A. (2004). Chile: Towards a migration policy. Migration Information Source.

El Telégrafo. (2014). La crisis bancaria de 1999 costó al país \$ 6.170 millones. El Telégrafo. Retrieved from http://www.eltelegrafo.com.ec/noticias/informacion-general/1/la-crisis-bancaria-de-1999-costo-al-pais-6-17 0 -millones

FACEA. (2012). Encuesta Trimestral de Ocupación y Desocupación en el Gran Santiago [Quarterly Survey of Employment and Unemployment in Greater Santiago]. Retrieved from http://www.empleo.microdatos.cl/encuesta_ocupacion/

Fleurant, A., Perlo-Freeman, S., Wezeman, P. D., Wezeman, S. T., \& Kelly, N. (2016). The SIPRI top 100 arms-producing and military services companies, 2015. Stockholm: Stockholm Peace Research Institute.

Fundar. (2005). El ranking de la violencia en América Latina. Buenos Aires: Fundación Fundar.

Gasparini, L., \& Lustig, N. (2011). The rise and fall of income inequality in Latin America. Society for the Study of Economic Inequality Working Paper.

Gilens, M., \& Page, B. I. (2014). Testing theories of American politics: Elites, interest groups, and average citizens. Perspectives on Politics, 12, 564-581.

Greenwald, G. (2011). With justice and liberty for some: How the law is used to destroy equality and protect the powerful. New York: Metropolitan Books.

Heston, A., Summers, R., \& Aten, B. (2011). Penn World Table Version 7.0. Philadelphia: Center for International Comparisons of Production, Income and Prices at the University of Pennsylvania. Retrieved from http://pwt.econ.upenn.edu/

Huntington, S. (1991). The Third Wave democratization in the Twentieth Century. Norman: University of Oklahoma Press.

In Sight Crime. (2016). In Sight Crime's 2015 Latin America Homicide Round-up. In Sight Crime. Retrieved from

http://www.insightcrime.org/news-analysis/insight-crime-homicide-round-up-2015-latin-america-caribbean

Jay, W. (1833). Life and opinions of John Jay (Vol. 1). New York: Harper.

Jokisch, B. (2014). Ecuador: From mass emigration to return migration? Migration Information Source: The Online Journal of the Migration Policy Institute. Washington D.C. Retrieved from http://www.migrationpolicy.org/article/ecuador-mass-emigration-return-migration

Kennan, G. (1948). Review of Current Trends, U.S. Foreign Policy. Policy Planning Staff, 23, 509-529. 
Kennan, G. (1950). 2nd Regional conference of US chiefs of mission in Rio de Janeiro. In Office files of the assistant secretary of state for Latin American affairs Edward G. Miller 1949-1953.

LaFeber, W. (1993). Inevitable revolutions: The United States in Central America. New York: W. W. Norton \& Company.

Latinobarómetro. (1997). Informe Latinobarómetro. Santiago. Retrieved from http://www.latinobarometro.org/latContents.jsp

Latinobarómetro. (2005). Informe Latinobarómetro. Santiago. Retrieved from http://www.latinobarometro.org/latContents.jsp

Meller, P. (2000). The Unidad Popular and the Pinochet Dictatorship: A political economy analysis. London: Palgrave Macmillan.

Minister of Energy and Mines, Petroecuador and Texpet. (1998). Acta final. Quito: Ministry of Energy and Mines.

Ostry, J., Loungani, P., \& Furceri, D. (2016). Neoliberalism oversold? Finance and Development. Retrieved from https://www.imf.org/external/pubs/ft/fandd/2016/06/pdf/ostry.pdf

Palma, G. (2014). Has the income share of the middle and upper-middle been stable over time, or is its current homogeneity across the world the outcome of a process of convergence? The "Palma Ratio" revisited. Cambridge Working Papers in Economics.

Pazy Miño, J. (2006). Ecuador: Una democracia inestable. Historia Actual Online.

Peláez, V. (2016). The prison industry in the United States: Big business or a new form of slavery? Global Research.

Przeworski, A. (1999). Minimalist conception of democracy: A defence. In Democracy's value. Cambridge: Cambridge University Press.

Ramírez, F., \& Ramírez, J. (2005). La estampida migratoria ecuatoriana: Crisis, redes transnacionales y repertorios de acción migratoria. Quito: Centro de Investigaciones Ciudad.

Restrepo, R. (2014). Independencia judicial y democracia en Ecuador. In Pugna de poderes, crisis orgánica e independencia judicial. Quito: Instituto de Altos Estudios Nacionales.

Restrepo, R., Vazquez, C., \& Garzón, K. (2016). The resource curse mirage: The blessing of resources and curse of empire? Real World Economics Review, 75. Retrieved from http://www.explored.com.ec/noticias-ecuador/corte-suprema-de-justicia-no-da-informacion-de-banqueros-2 71883.html

Roemer, J. (1999). Does democracy engender justice? In Democracy's value. Cambridge: Cambridge University Press.

Ruiz, M., \& Cisneros, P. (2014). Crisis de hegemonía y recomposición del pacto estatal ecuatoriano, 1990-2008. In Pugna de poderes, crisis orgánica e independencia judicial. Quito: Instituto de Altos Estudios Nacionales.

Sarmiento, M., \& Rivera, L. (2013). La muerte de Jaime Roldós. Quito: La Maquinita.

Schumpeter, J. (1942). Capitalismo, socialismo y democracia. London: Harper and Brothers.

United Nations. (1969). Vienna Convention on the Law of Treaties. United Nations.

UNODC. (2013). Intentional Homicide, Count and Rate per 100,000 Population. In Global Study on Homicide. New York: United Nations Office on Drugs and Crime.

Unrevealed author. (1975). Review of Inside the Company: A diary of the CIA. Studies in Intelligence.

Weisbrot, M. (2015). Failed: What the experts got wrong about the global economy. Oxford: Oxford University Press.

Weisbrot, M., \& Ray, R. (2011). The scorecard on development. Washington: UN, CEPR.

Wenar, L. (2008). Property rights and the resource curse. Philosophy \& Public Affairs, 36, 2-32.

World Health Organization. (n.d.). Statistics on Homicides, Suicides, Accidents, Injuries, \& Attitudes towards Violence. Retrieved from http://www1.paho.org/English/AD/DPC/NC/violence-graphs.htm\#homicides-n-sa 
Zeitchik, A. (2014). Sludge match: Inside chevron's 9 billion legal battle with Ecuadorian villagers. Rolling Stone. Retrieved from http://www.rollingstone.com/politics/news/sludge-match-chevron-legal-battle-ecuador-steven-donziger-201 40828

\section{Notes}

Note 1.16 days before the plane crash, in a memo recently declassified under the Freedom of Information Act, the CIA predicted that while the military would not directly take the face of power, they would overthrow Roldós "immediately" and other civilians involved would take over in a "marriage of convenience". Part of the memo reads that "The military, which could depose Roldós immediately, has thus far evidenced no inclination to return to power. Disaffected politicians, on the other hand, are steadily increasing the level and tempo of their attacks... could provide the impetus for a marriage of convenience between civilians and dissident military elements..." (CIA, 1981). Thanks to Jeremy Bigwood for activating the declassification of this document and sharing it with me. Specific further direct US involvement has not been declassified at the time. It should be remembered, however, that it would not fall out of historical policy patterns toward the region. The US identified Latin American "raw materials" as "ours" and governments who aim to take control of their natural resources to satisfy domestic needs as the principal threat to US interests, which would not be tolerated (Kennan, 1948, 1950; LaFeber, 1993). Further, not to mention other regional implementations of this policy, the CIA installed the repressive Ecuadorian military dictatorship of 1963 (Agee, 1975), a fact that the CIA's own in-house journal does not deny (Unrevealed author, 1975), and which introduced Texaco to the country, a company that would significantly destroy the Amazon and murder thousands by knowingly contaminating their water and soil (Zeitchik, 2014).

Note 2. The release, however, did not include liabilities to non-state actors, which is the basis of the lawsuit brought by 30,000 indigenous and other local inhabitants.

\section{Copyrights}

Copyright for this article is retained by the author(s), with first publication rights granted to the journal.

This is an open-access article distributed under the terms and conditions of the Creative Commons Attribution license (http://creativecommons.org/licenses/by/4.0/). 